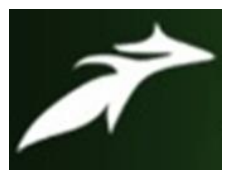

Kumar Saurabh et al, International Journal of Advances in Agricultural Science \& Technology,

Vol.8 Issue.11, November-2021, pg. 28-40

ISSN: 2348-1358

Impact Factor: 6.057

NAAS Rating: 3.77

\title{
A Study on Knowledge and Utilization of Soil Health Card by Small and Marginal Farmers in Nalanda District of Bihar
}

\author{
Kumar Saurabh*; Dr. Syed H.Mazhar**; Dr. Dipak Kumar Bose*** \\ *Research Scholar, Department of Agricultural Extension \& Communication, SHUATS, Prayagraj \\ **Associate Professor, Department of Agricultural Extension \& Communication, SHUATS, Prayagraj \\ ***Associate Professor, Department of Agricultural Extension \& Communication, SHUATS, Prayagraj \\ DOI: 10.47856/ijaast.2021.v08i11.004
}

\begin{abstract}
Soil health and fertility is the basis for sustainable profitability of the farmers.Hence, there is a need for balanced use of fertilizers, keeping this government of India introduced Soil Health Card Scheme across India. On 5th December 2015 the ministry of agriculture introduced the soil health card (SHC) scheme.Some farmers complained that the soil test values are not representative of their fields and they also complained that the field staff are not collected soil samples in their presence.In this background an attempt was made to study the impact on socio-economic conditions of the small and marginal farmers. Total of 120 respondents was selected in Ekangarsarai block, Nalanda district, Bihar by purposive sampling method. The data was collected from them and analyzed using MS-excel.Given the short duration of the scheme, knowledge levels are good. At the same time participation of farmers in meetings, exposure visits are not high. Awareness campaigns need to be organized on content of SHCs, use of recommended practices, reduction in fertilizer use and costs and increase in profitability.
\end{abstract}

Keywords: Soil Health Card, Awareness, Knowledge and Extension of utilization 


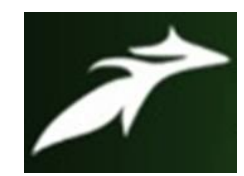

Kumar Saurabh et al, International Journal of Advances in Agricultural Science \& Technology, Vol.8 Issue.11, November-2021, pg. 28-40

ISSN: 2348-1358

Impact Factor: 6.057

NAAS Rating: 3.77

\section{Introduction:}

Soil health and fertility is the basis for sustainable profitability of the farmers. Using optimal doses of fertilizers and cropping pattern as per the scientific recommendation is the first step towards sustainable farming. Soil testing is a science based and time-tested tool for assessment of soil fertility status and soil ailments and for nutrient amendment recommendations. Soil testing, as a tool for judicious fertilizer use, works on the principle of profitability, meaning if all other factors of production are at optimum and none of them limiting, there is all probability to obtain more profitable response to applied nutrients based on soil testing than those applied on adhoc basis. In India, the current consumption of NPK ratio is 6.7:2.4:1, which is highly skewed towards nitrogen as against ideal ratio of $4: 2: 1$. India is spending nearly Rupees Seventy thousand crore on fertilizer subsidy every year (Gulati 2020). According to the estimates, subsidy amount is about Rs.5000/ha of net cropped area and about Rs.5100/farmer resulting in excessive use of fertilizers, especially NPK at the cost of micronutrients and manure (Makadia 2012). Hence, there is a need for balanced use of fertilizers, keeping this government of India introduced Soil Health Card Scheme across India. On 5th December 2015 the ministry of agriculture introduced the soil health card (SHC) scheme. The SHC scheme has been approved for implementation during the remaining period of 12th plan. SHC will be provided to all farmers in the country at an interval of 2 years to enable the farmers to apply recommended doses of nutrients based on soil test values to realize improved and sustainable soil health and fertility, low costs and higher profits. Under SHC scheme, cropped area was divided in to grids of 10 ha for rainfed and 2.5 ha for irrigated. One soil sample from each grid will be taken and test results will be distributed to all the farmers whose lands fall under the grid. Based on the grid system, of the total 14.1 crore hectare of net cropped area, 73 lakh grid samples to be collected to cover 7.3 crore ha in rain-fed areas and 2.7 crore grid samples to be collected to cover 6.8 crore ha irrigated land. That is, a total of 3.46 crore grid samples in two years (1.73 crore grid samples per year). And, an average of 25000 grid samples per district/year or 29 grid samples per village/year. With this, all 11 crore farmers will be 


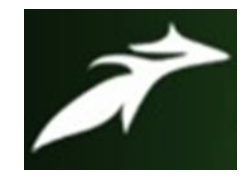

Kumar Saurabh et al, International Journal of Advances in Agricultural Science \& Technology, Vol.8 Issue.11, November-2021, pg. 28-40

ISSN: 2348-1358

Impact Factor: 6.057

NAAS Rating: 3.77

covered in two years (Grover 2016). Every year 5.2 crore farmers need to be covered.Some farmers complained that the soil test values are not representative of their fields and they also complained that the field staff are not collected soil samples in their presence.Awareness campaigns need to be organized the use of SHC in reduction in fertilizer use and costs and increase in yields. Many farmers feel that SHC should also mention one or two physical and micro-biological indicators (such as soil texture, water holding capacity, and water quality and bacterial content). There is a need to identify best practices in soil sample collection (predetermined DRID apps practiced in Punjab and TN) and testing for scale-up.The research problem selected is in line with current issues and has practical utility for agricultural stakeholders and of academic importance (Chowadry 2017).Ranganath (2019) conducted a study on Knowledge and attitude towards SHC found that majority of the farmers (55.83\%) were having a more favorable attitude towards SHC.Ranjitet.al. (2019) revealed that more than half of the respondents showed favorable attitude SHC (55.00\%). On the contrary 35.00 per cent and 10.00 per cent of the respondents had neutral and unfavorable attitude towards SHC respectively. In this background an attempt was made to study the impact on socio-economic conditions of the small and marginal farmers. There is no study taken in assessment of knowledge and utilization of soil health card by small and marginal farmers in Nalanda district of Bihar.

\section{Methodology:}

Nalanda district occupies an area of 2,355 square kilometers (909 sq. mi), comparatively equivalent to Canada's Cornwall Island. Majority of the land in the district is fertile land of Indo Gangetic plane. In the extreme South, there lies the hills of Rajgir. There are 20 blocks out of that Ekangarsarai block is selected for present study in that Six village's was selected purposely based on the maximum area covered under soil health card (SHC).Total of 120 respondents was selected by purposive sampling method. The data was collected from them and analyzed using MS-excel. 


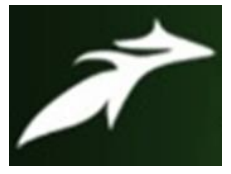

Kumar Saurabh et al, International Journal of Advances in Agricultural Science \& Technology, Vol.8 Issue.11, November-2021, pg. 28-40

ISSN: 2348-1358

Impact Factor: 6.057

NAAS Rating: 3.77

\section{Results and Discussion:}

Table 1: Distribution of respondents according to their socio-economic profile characteristics

\begin{tabular}{|c|c|c|c|c|}
\hline S. No. & Variables & Category & Number & Per cent \\
\hline \multirow{3}{*}{1.} & \multirow{3}{*}{ Age } & Young & 18 & 15.00 \\
\hline & & Middle & 90 & 75.00 \\
\hline & & Old & 12 & 10.00 \\
\hline \multirow{7}{*}{2.} & \multirow{7}{*}{$\begin{array}{l}\text { Educational } \\
\text { status }\end{array}$} & Illiterate & 16 & 13.33 \\
\hline & & Functionally Illiterate & 06 & 05.00 \\
\hline & & Primary School (1-5) & 18 & 15.00 \\
\hline & & Middle school (6-8) & 30 & 25.00 \\
\hline & & High school education (9-10) & 28 & 23.33 \\
\hline & & $\begin{array}{l}\text { Higher secondary school } \\
\text { education }(11-12)\end{array}$ & 16 & 13.33 \\
\hline & & Collegiate education & 06 & 05.00 \\
\hline \multirow{4}{*}{3.} & \multirow{4}{*}{ Family size } & $\begin{array}{l}\text { Small sized family (up to } 3 \\
\text { members) }\end{array}$ & 36 & 30.00 \\
\hline & & $\begin{array}{l}\text { Medium sized family }(4-5 \\
\text { members) }\end{array}$ & 48 & 40.00 \\
\hline & & $\begin{array}{l}\text { Large sized family } \quad(6-7 \\
\text { members })\end{array}$ & 20 & 16.67 \\
\hline & & $\begin{array}{l}\text { Very large sized family (above } \\
7 \text { members) }\end{array}$ & 16 & 13.33 \\
\hline \multirow{2}{*}{4.} & \multirow{2}{*}{ Land holding } & Small farmers & 74 & 61.67 \\
\hline & & Marginal farmers & 46 & 38.33 \\
\hline 5. & Annual Income & Low (< Rs. 50,000) & 90 & 75.00 \\
\hline
\end{tabular}




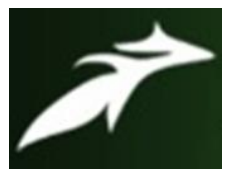

Kumar Saurabh et al, International Journal of Advances in Agricultural Science \& Technology, Vol.8 Issue.11, November-2021, pg. 28-40

ISSN: 2348-1358

Impact Factor: 6.057

NAAS Rating: 3.77

\begin{tabular}{|c|c|c|c|c|}
\hline & & $\begin{array}{l}\text { Medium (Rs. 50,001 - Rs. } \\
1,00,000)\end{array}$ & 22 & 18.33 \\
\hline & & High (>Rs. $1,00,000)$ & 08 & 06.67 \\
\hline \multirow{3}{*}{6.} & \multirow{3}{*}{$\begin{array}{l}\text { Social } \\
\text { Participation }\end{array}$} & Low & 60 & 50.00 \\
\hline & & Medium & 28 & 23.33 \\
\hline & & High & 32 & 26.67 \\
\hline \multirow{3}{*}{7.} & \multirow{3}{*}{$\begin{array}{l}\text { Mass media } \\
\text { utilization }\end{array}$} & Low & 26 & 21.66 \\
\hline & & Medium & 56 & 46.67 \\
\hline & & High & 38 & 31.67 \\
\hline \multirow{3}{*}{8.} & \multirow{3}{*}{$\begin{array}{l}\text { Extension } \\
\text { Agency } \\
\text { contact }\end{array}$} & Low & 24 & 20.00 \\
\hline & & Medium & 56 & 46.67 \\
\hline & & High & 40 & 33.33 \\
\hline
\end{tabular}

From table 01, it was evident that preponderance of the farmers of SHC scheme falls under middle age category (75.00\%), followed by young (15.00\%) and old (10.00\%), This shows both small and marginal farmers falls under middle age category but the difference arise in the old and young category, the small and marginal farmers of young age had become the respondents of SHC scheme more than the old farmers since due to the awareness and knowledge gain, one-fourth $(25.00 \%)$ of the farmershad completed their middle school education, 23.33 per cent and 15.00 per cent of the farmers had received high school and primary level education, about 13.33 per cent of the farmers were illiterate and again 13.33 per cent of the small and marginal farmers had higher secondary school education, few $(05.00 \%)$ of the farmers remains to be functionally illiterate and collegiate education was completed by $05.00 \%$ of the small and marginal farmers, majority $(40.00 \%)$ of the farmers came from medium sized family (4-5 members). About 30.00 and 16.67 per cent of the respondents belonged to small sized family and large sized family respectively. Only 13.33 per cent of the farmers hailed from very large sized family.Majority(75.00\%) of the respondents were having annual income of less 


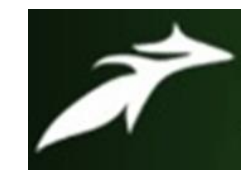

Kumar Saurabh et al, International Journal of Advances in Agricultural Science \& Technology, Vol.8 Issue.11, November-2021, pg. 28-40

ISSN: 2348-1358 Impact Factor: 6.057

NAAS Rating: 3.77

than fifty thousandrupees followed by 18.33 per cent respondents were having annual income of fifty thousand one rupees to one lakh rupees and 06.67 per cent of the respondents were having annual income of more than one lakh rupees. More than half $(61.67 \%)$ of the respondents were found to be small farmers followed by 38.33 per cent of the respondents were found to marginal farmers and in this study we didn't consider the big famers. Majority $(50.00 \%)$ of the respondents had low level of social participation followed by 23.33 per cent of the respondents had high and medium level of social participation respectively and remaining 26.67 per cent respondents had medium and high level of social participation.Nearly than half $(46.67 \%)$ of the small and marginal farmers of SHC scheme had medium level of mass media utilization. About 31.67 per cent small and marginal farmers of SHC scheme had utilized mass media highly. Only 21.66 per cent of the small and marginal farmers of SHC scheme had utilized mass media to the minimally.Majority (46.67\%) of the small and marginal farmers had medium level of extension agency contact respectively followed by 33.33 per cent of the small and medium farmers had high of extension agency contact respectively. About 20.00 per cent of the small and marginal farmers developed low level of extension agency contact respectively.

Table 2: Distribution of respondents according to their individual level of knowledge regarding SHC scheme

\begin{tabular}{|c|l|c|c|}
\hline \multirow{2}{*}{ S.No. } & \multicolumn{1}{|c|}{ Statement } & \multicolumn{2}{|c|}{ Respondents } \\
\cline { 3 - 4 } & & Yes & No \\
\hline 1. & $\begin{array}{l}\text { Soil health card provides information regarding the } \\
\text { status of available nutrients(Macro \& Micro) in the soil }\end{array}$ & $114(95 \%)$ & 06 \\
$(05 \%)$
\end{tabular}




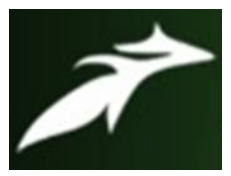

Kumar Saurabh et al, International Journal of Advances in Agricultural Science \& Technology, Vol.8 Issue.11, November-2021, pg. 28-40

ISSN: 2348-1358

Impact Factor: 6.057

NAAS Rating: 3.77

\begin{tabular}{|c|c|c|c|}
\hline 3. & $\begin{array}{l}\text { Soil health card helps farmers in reducing extra } \\
\text { expenditure by supplying required nutrients in the soil. }\end{array}$ & $\begin{array}{c}100 \\
(83 \%)\end{array}$ & $\begin{array}{c}20 \\
(17 \%)\end{array}$ \\
\hline 4. & $\begin{array}{l}\text { The soil health card helps the farmers to get an idea on } \\
\text { the crop wise recommendation of nutrients and } \\
\text { fertilizers required in each type of soil }\end{array}$ & $110(92 \%)$ & $\begin{array}{c}10 \\
(08 \%)\end{array}$ \\
\hline 5. & $\begin{array}{l}\text { Soil health card can be helpful and effective only if the } \\
\text { recommendations are followed by farmers on regular } \\
\text { basis }\end{array}$ & $\begin{array}{c}96 \\
(80 \%)\end{array}$ & $\begin{array}{c}24 \\
(20 \%)\end{array}$ \\
\hline 6. & $\begin{array}{l}\text { The technical information provided in soil health card } \\
\text { has been made available in local language }\end{array}$ & $86(72 \%)$ & $34(28 \%)$ \\
\hline 7. & $\begin{array}{l}\text { Soil health card helps in practicing farming in scientific } \\
\text { way }\end{array}$ & $106(88 \%)$ & $14(12 \%)$ \\
\hline 8. & $\begin{array}{l}\text { Soil health card helps to check the excessive use of } \\
\text { fertilizer }\end{array}$ & $\begin{array}{c}94 \\
(78 \%)\end{array}$ & $\begin{array}{c}26 \\
(22 \%)\end{array}$ \\
\hline 9. & $\begin{array}{l}\text { Soil health cards provides clue to health of farm and its } \\
\text { strength and weakness in terms of different nutrients and } \\
\text { organic carbon ingredients }\end{array}$ & $\begin{array}{c}98 \\
(82 \%)\end{array}$ & $\begin{array}{c}22 \\
(18 \%)\end{array}$ \\
\hline 10. & $\begin{array}{l}\text { Expenditure of crop production decreases after soil } \\
\text { testing }\end{array}$ & $\begin{array}{c}90 \\
(75 \%)\end{array}$ & $\begin{array}{c}30 \\
(25 \%)\end{array}$ \\
\hline
\end{tabular}




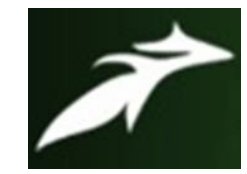

Kumar Saurabh et al, International Journal of Advances in Agricultural Science \& Technology, Vol.8 Issue.11, November-2021, pg. 28-40

ISSN: 2348-1358 Impact Factor: 6.057

NAAS Rating: 3.77

From table 2, it was found that majority of farmers (95\%) had knowledge about the soil health card provide information about the status of available nutrients (Macro \& Micro) in the soil, Similarly Soil Health Card help the farmers to cultivate the crop in more scientific way by adopting recommended dose of fertilizers and required input in particular field (88\%). which provide corrective measure for improving soil health and for getting better yield (85\%). In further investigation majority of farmers (83\%) were aware that Soil Health Card helps in reducing extra expenditure by supplying required nutrients status in the soil and It was observed that most of the farmers $(82 \%)$ were aware that Soil health cards provides clue to health of farm and its strength and weakness in terms of different nutrients and organic carbon ingredients followed by expenditure of crop production decreases after soil testing (75\%), number of crops increased in one year after soil testing (78\%) and technical information provided in soil health card has been made available in local language (72\%).Jaiswal et al. (2018) in his study found that majority of farmers $(79.17 \%)$ were awareness about utility of Soil Health Card.

Table 3: Distribution of respondents according to their knowledge level

\begin{tabular}{|c|l|c|c|}
\hline S.No. & \multicolumn{2}{|c|}{ Category } & \multicolumn{2}{c|}{ Respondents } \\
\cline { 3 - 4 } & & Number & Per cent \\
\hline 1. & Low & 24 & 20.00 \\
\hline 2. & Medium & 80 & 66.67 \\
\hline 3. & High & 16 & 13.33 \\
\hline 4. & Total & 60 & 100.00 \\
\hline
\end{tabular}

It could be understand from the table 3, that preponderance of the respondents had medium level of knowledge (66.67\%), followed by low (20.00\%) and high (13.33\%) level of knowledge, the knowledge of small and marginal farmers gives value and reliability, 


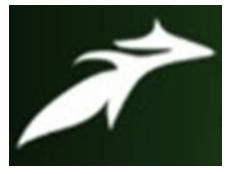

Kumar Saurabh et al, International Journal of Advances in Agricultural Science \& Technology, Vol.8 Issue.11, November-2021, pg. 28-40

ISSN: 2348-1358

Impact Factor: 6.057

NAAS Rating: 3.77

Table 4: Distribution of respondents according to their extent of utilization in respect of SHC regarding crop production technology

\begin{tabular}{|c|c|c|c|c|}
\hline \multirow{2}{*}{ S. No. } & \multirow{2}{*}{ Category } & \multicolumn{3}{|c|}{ Extent of utilization } \\
\hline & & Low & Medium & High \\
\hline 1. & Ploughing and land preparation & $\begin{array}{c}12 \\
(10 \%)\end{array}$ & $\begin{array}{c}96 \\
(80 \%)\end{array}$ & $\begin{array}{c}12 \\
(10 \%)\end{array}$ \\
\hline 2. & Improved varieties of Soybean & $\begin{array}{l}14 \\
(\%)\end{array}$ & $\begin{array}{l}102 \\
(\%)\end{array}$ & $\begin{array}{c}04 \\
(\%)\end{array}$ \\
\hline 3. & Seed treatment & $\begin{array}{c}24 \\
(20 \%)\end{array}$ & $\begin{array}{c}94 \\
(78 \%)\end{array}$ & $\begin{array}{c}02 \\
(02 \%)\end{array}$ \\
\hline 4. & Soil type & $\begin{array}{c}32 \\
(27 \%)\end{array}$ & $\begin{array}{c}84 \\
(70 \%)\end{array}$ & $\begin{array}{c}04 \\
(03 \%)\end{array}$ \\
\hline 5. & Method of sowing & $\begin{array}{c}06 \\
(05 \%)\end{array}$ & $\begin{array}{c}102 \\
(93 \%)\end{array}$ & $\begin{array}{c}02 \\
(02 \%)\end{array}$ \\
\hline 6. & Cropping pattern & $\begin{array}{c}28 \\
(23 \%)\end{array}$ & $\begin{array}{c}82 \\
(69 \%)\end{array}$ & $\begin{array}{c}10 \\
(06 \%)\end{array}$ \\
\hline 7. & Cropping diversification & $\begin{array}{c}22 \\
(18 \%)\end{array}$ & $\begin{array}{c}86 \\
(72 \%)\end{array}$ & $\begin{array}{c}12 \\
(10 \%)\end{array}$ \\
\hline 8. & Type of fertilizer & $\begin{array}{c}14 \\
(12 \%)\end{array}$ & $\begin{array}{c}98 \\
(81 \%)\end{array}$ & $\begin{array}{c}08 \\
(07 \%)\end{array}$ \\
\hline 9. & Fertilizer dose application & $\begin{array}{c}20 \\
(17 \%)\end{array}$ & $\begin{array}{c}96 \\
(80 \%)\end{array}$ & $\begin{array}{c}04 \\
(03 \%)\end{array}$ \\
\hline 10. & Integrated weed management & $\begin{array}{c}18 \\
(15 \%)\end{array}$ & $\begin{array}{c}100 \\
(83 \%)\end{array}$ & $\begin{array}{c}02 \\
(02 \%)\end{array}$ \\
\hline
\end{tabular}




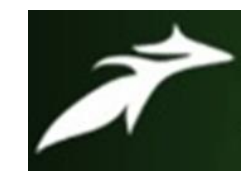

Kumar Saurabh et al, International Journal of Advances in Agricultural Science \& Technology, Vol.8 Issue.11, November-2021, pg. 28-40

ISSN: 2348-1358

Impact Factor: 6.057

NAAS Rating: 3.77

\begin{tabular}{|c|l|c|c|c|}
\hline 11. & Integrated pest management & $\begin{array}{c}10 \\
(08 \%)\end{array}$ & $\begin{array}{c}106 \\
(89 \%)\end{array}$ & $\begin{array}{c}04 \\
(03 \%)\end{array}$ \\
\hline 12. & Level of production & 06 & 110 & 04 \\
& & $(05 \%)$ & $(92 \%)$ & $(03 \%)$ \\
\hline
\end{tabular}

i. Extent of utilization regarding ploughing and land preparation, out of the total respondents, majority of the respondents $(80.00 \%)$ pertained medium level of utilization followed by low (10\%) and high (10\%) level of utilization.

ii. Extent of utilization regarding improved varieties, out of the total respondents, majority of the respondents $(85 \%)$ pertained medium level of utilization followed by low (12\%) and high (03\%) level of utilization.

iii. Extent of utilization regarding seed treatment, out of the total respondents, majority of the respondents $(78 \%)$ pertained medium level of utilization followed by low (20\%) and high (02\%) level of utilization.

iv. Extent of utilization regarding soil type, out of the total respondents, majority of the respondents $(70 \%)$ pertained medium level of utilization followed by low (27\%) and high (03\%) level of utilization.

v. Extent of utilization regarding method of sowing, out of the total respondents, majority of the respondents $(93 \%)$ pertained medium level of utilization followed by low (05\%) and high (02\%) level of utilization.

vi. Extent of utilization regarding cropping pattern, out of the total respondents, majority of the respondents $(69 \%)$ pertained medium level of utilization followed by low (23\%) and high (06\%) level of utilization. 


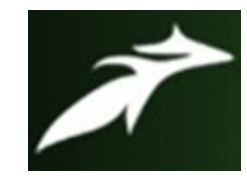

Kumar Saurabh et al, International Journal of Advances in Agricultural Science \& Technology, Vol.8 Issue.11, November-2021, pg. 28-40

ISSN: 2348-1358

Impact Factor: 6.057

NAAS Rating: 3.77

vii. Extent of utilization regarding cropping diversification, out of the total respondents'majority of the respondents $(72 \%)$ pertained medium level of utilization followed by low $(18 \%)$ and high $(10 \%)$ level of utilization.

viii. Extent of utilization regarding type of fertilizers, out of the total respondents, majority of the respondents $(81 \%)$ pertained medium level of utilization followed by low (12\%) and high (07\%) level of utilization.

ix. Extent of utilization regarding Fertilizer dose application, out of the total respondents, majority of the respondents $(80 \%)$ pertained medium level of utilization followed by low (17\%) and high $(03 \%)$ level of utilization.

x. Extent of utilization regarding integrated weed management, out of the total respondents, majority of the respondents $(83 \%)$ pertained medium level of utilization followed by low (15\%) and high $(02 \%)$ level of utilization.

xi. Extent of utilization regarding integrated pest management, out of the total respondents, majority of the respondents(89\%) pertained medium level of utilization followed by low (18\%) and high $(03 \%)$ level of utilization.

xii. Extent of utilization regarding level of production, out of the total respondents, majority of the respondents(92\%) pertained medium level of utilization followed by low (05\%) and high $(03 \%)$ level of utilization. 


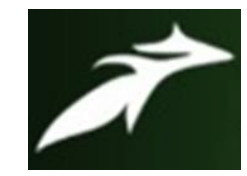

Kumar Saurabh et al, International Journal of Advances in Agricultural Science \& Technology, Vol.8 Issue.11, November-2021, pg. 28-40

ISSN: 2348-1358 Impact Factor: 6.057

NAAS Rating: 3.77

Table 5: Distribution of respondents according to their overall extent of utilization of SHC

\begin{tabular}{|c|l|c|c|}
\hline S.No. & \multicolumn{2}{|c|}{ Category } & \multicolumn{2}{c|}{ Respondents } \\
\cline { 3 - 4 } & & Number & Per cent \\
\hline 1. & Low & 16 & 13.33 \\
\hline 2. & Medium & 94 & 78.34 \\
\hline 3. & High & 10 & 08.33 \\
\hline 4. & Total & 60 & 100.00 \\
\hline
\end{tabular}

From table 5, It was evident that higher percentage of the respondents had medium level of extent of utilization (78.34\%), followed by low (13.33\%) and high (08.33\%) level of extent of utilization.

\section{Conclusion:}

Given the short duration of the scheme, knowledge and utilization levels are good. At the same time participation of farmers in meetings, exposure visits are not high. Awareness campaigns need to be organized on content of SHCs, use of recommended practices, reduction in fertilizer use and costs and increase in profitability. There is no apparent or significant bias against socio-economically vulnerable sections. In contrast, small and marginal farmers benefit more in some cases. There is some reduction in fertilizer use, especially nitrogen and increase in bio-fertilizers and other micro-nutrients use. This is a good sign as N: P: K ratio was highly skewed towards nitrogen. Costs were reduced due to low fertilizer use. Crop yields have also increased for majority of the crops, although only moderately. Agricultural officers and agricultural extension officers' need to be given appropriate training, transport and easy to use sampling tools and incentives for scientific sample collection. 


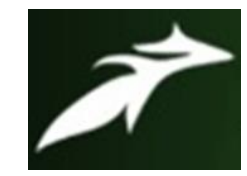

Kumar Saurabh et al, International Journal of Advances in Agricultural Science \& Technology, Vol.8 Issue.11, November-2021, pg. 28-40

ISSN: 2348-1358

Impact Factor: 6.057

NAAS Rating: 3.77

\section{References}

[1]. Chowdary, R.K., Theodore, RK.,Anandarja, N., Santhi, R. 2017. Factors Determining the Use of Soil Health Card (SHC) Recommendations in Kurnool District of Andhra Pradesh. International Journal of Pure \& Applied Bioscience, 5 (6): 1689-1694.

[2]. Grover D. K., Singh J. M., Singh J. and Kumar S. 2016. Soil-test based fertilizer usage: A step towards sustainable agriculture in Punjab. Indian Journal of Econ Dev 12: 493-500.

[3]. Gulati, A., Devesh, K., Bouton, M. M. 2020, Refroming Indian agriculture. Economic and Political Weekly, LV (11), 35-42.

[4]. Jaiswal, M., and Singh, A. 2018 Study on awareness \& perception regarding soil health card. Journal of Pharmacognosy and Phytochemistry; SP4: 395-400.

[5]. Makadia J. J. 2012. Regional imbalances and impact of Soil Health Card on fertilizer consumption in Gujarat.

[6]. Ranganath, A.D.., 2019, A study on self-help centers in on respondents, Ph.D. Thesis, Marathwada Agriculture University, Parbhani.

[7]. Ranjit J. D., Mani, G., Shetty, S. L., Karamkar, V. M. 2019, Trends and patterns of households indebtedness. Economic and Political Weekly, 54(9): 41-49. 